\title{
Eski Manyas'ta Erken Osmanlı Dönemine Ait Zaviyeli Cami ve Türbe
}

\author{
Halil SÖZLÜ*
}

\begin{abstract}
ÖZ
Erken Osmanlı Çăğı'nda önemli rol oynayan Balıkesir, bünyesinde bu döneme ait kültürel varlıkları barındırmaktadır. Makalemizde, öncelikle Eski Manyas'ın tarihsel süreç içerisinde geçirdiği dönemler üzerinde durulmuştur. Bölgenin tarih boyunca farklı isimlerle anıldığ1 ve kesintisiz bir yerleşim alanı olduğu bilinmektedir. Roma, Bizans, Beylikler ve Osmanlı döneminde Manyas'ın etkin olarak kullanılan bir yer olduğu görülmektedir. Özelde Manyas'a, genelde ise Balıkesir'e baktığımız zaman bu dönemlere ait mimari yapıların zenginliği göze çarpmaktadır. Çalışmamızda, Balıkesir’in Manyas ilçesi eski Manyas harabelerinde bulunan Erken Osmanlı dönemi özellikleri yansıtan Zaviyeli Cami ve Türbe incelenmiştir. Özgün hâlleriyle günümüze kadar ulaşmı̧̧ bu yapılar, zamana karşı koyarak ayakta kalmaya çalışmaktadır. Araştırma kapsamında yapılar yerinde görülerek, ölçüleri alınarak çizimleri yapılmış ve fotoğraflar eşliğinde ayrıntılı bir şekilde tanıtılmış, dönem içerisindeki benzer örnekleriyle karşılaştırmalar yapılmıştır. Caminin zaviyeli yapılar grubunda olması ve ilk inşa döneminden izleri bugüne kadar taşıması bakımından önemi vurgulanması gerekmektedir. Bu düşünceyle yürütülen bu çalışmada, zaviyeli caminin, mimari form ve özellikleri, kullanılan malzemeler ile plan açısından irdelenmesi yapılmıştır. Yapılan bu araştırma sonrasında caminin aynı plan türüne sahip camiler içerisinde farklı ve önemli özelliklere sahip olduğu anlaşılmıştır. Süsleme bakımından sade olan yapılarda herhangi bir bezemeye rastlanmamıştır. Türbenin de Erken Dönem Osmanlı mimari üslubuna uygun bir biçimde inşa edildiği anlaş1lmıştır. Sonuç kısmında, yapıların dönem içerisindeki yerleri ve önemleri belirtilerek korunması ve onarımlarının yapılmasına yönelik önerilerimiz dile getirilmiştir.
\end{abstract}

Anahtar Kelimeler: Osmanl1, Balıkesir, Manyas, Mysia, zaviyeli camiler, türbe.

Dr. Öğr. Üyesi, Mersin Üniversitesi Fen Edebiyat Fakültesi Sanat Tarihi Bölümü, Mersin/ Türkiye E-posta: halilsozlu@mersin.edu.tr, ORCID:0000-0002-3100-486X,DOI:10.32704/erdem.838773 Makale Gönderim Tarihi: 18.11.2019* Makale Kabul Tarihi: 22.07.2020 * (Araştırma Mk.) 


\title{
The Mosque With Zaviyah and Tomb From The Early Ottoman Period In Old Manyas
}

\begin{abstract}
Balıkesir, which played an important role during the Early Ottoman period, includes cultural heritage belonging to this period. In our article, first of all, the periods of Old Manyas in the historical process are focused on. It is known that the region has been called by different names throughout history and that it is an uninterrupted settlement area. It is seen that Manyas was used effectively during the Roman, Byzantine, Principalities (Anatolian Beyliks), and Ottoman eras. When we look at Manyas in particular and Balıkesir province in general, the richness of the architectural structures of these periods stands out. In our study, the Mosque with Zaviyah and Tomb which reflecting the architectural features of the Early Ottoman period in the old city of Manyas district, Balıkesir were examined. These structures, which have survived to the present day in their original form, are trying to survive by resisting time. Within the scope of the research in the area, the structures examined, measured, plan drawings were made and introduced in detail with photographs, and made comparisons with similar examples during the same period. It should be emphasized that the mosque is important in terms of being in the group of structures with lodges and carrying the traces of the first building period up today. In this study, the architectural form and features of the Zaviyah Mosque were examined in terms of the materials and the plan. After this research, it was understood that the mosque has originality and importance within the mosques with the same type of plan. There is no decoration in the buildings which are plain in terms of ornamentation. It was understood that the tomb also was built by the Early Ottoman architectural style. In the conclusion section, we stated the places during the period and the historical value of the buildings. And also we expressed our suggestions for the conservation and restoration of the buildings.
\end{abstract}

Keywords: Ottoman, Balıkesir, Manyas, Mysia, zaviyah mosque, tomb. 


\section{Giriş}

M akalede $^{1}$ konu alınan yapılar günümüzde, Balıkesir’in Manyas ilçesi Eski Manyas Köyü mevkiinde bulunmaktadır. Eski Kale Harabesi, Maltepe ismi verilen bir tepe üzerinde yer almaktadır. Eski kasaba ve civarına Pemaninum veya Poemanenum ismi verilmiştir. Pemaninos bir askeri mevkidir. Ortaçağ'da Roma, Bizans ve Karesioğulları Beyliği dönemlerinde süreklilik gösteren bir yerleşim yeridir.

Bölgenin adı çeşitli kaynaklarda çok farklı geçmektedir. Poimanenon isminin etnik olduğu çok açıktır. Civardaki yerleşimlerde olduğu gibi, Yunanistan'ın kuzey kısımlarındaki bir yerleşim olan Poemaneni'den etkilenmiş gibi görülmektedir (Hasluck 1906'dan aktaran Şatıroğlu, 2010: 5).

Ramsey eserinde (Ramsey 1960: 170), “Lolling Athenische Mittheilungen'in, Gönen'de bulunmuş olan bir kitabeden hareketle Poimanenon arazisinin Gönen'e kadar uzandığı" görüşünde olduğunu ifade etmektedir. Poimanenon'un Misya topografyasında tam olarak nerede olduğu birçok araştırmacı tarafından tartışılmıştır. Poimanenon'un yeri ile ilgili tartışmalar, Roma yol sistemi ve Bizans savaşları olmak üzere iki farklı bakış açısı etrafinda toplanmıştır. Aristides'in kullandığ 1 yolu kanıt olarak kabul edenler yerleşimin Gönen'de Aesepus veya Tarsius Vadisi'nde olabileceği konusunda hem fikir iken, Bizans savaşlarını kanıt kabul edenler ise yerleşmenin Manyas Gölü'nün yaklaşık 15 km güneyinde yer alan Eski Manyas'ta olması gerektiğini savunmaktadır (Şatıroğlu 2010: 6).

Mysia bölgesi İznik’te kurulan Laskarisler devletinin genişleyip, güçlenmesini engellemek amacıyla 13.yüzyılın başlarından itibaren Latin ordularının saldırılarına maruz kalmıştır. I. Theodoros döneminde 1204 yılında Tophisar'ın güneyinde önemli bir stratejik mevki olan Poemanenum'daki savaşta Laskarisler, 1205 yılında ise Edremit çevresinde Latinler yenilmiştir (Ötüken 1988: 91).

1261 y1lında İstanbul'un Latinlerden geri alınması ve Palaiologoslar sülalesinin imparatorluğun başına geçmesiyle başlayan son dönemde, Mysia bölgesinde yeni kurulan Türk devletlerinin güçlendiği görülmektedir. 1269 yılında Kalem Bey ve oğlu Karesi Bey tarafından kurulan Karesi Beyliği Balıkesir'i merkez yaparak ve kısa sürede Eski Manyas ve çevresinde egemen olmuştur (Yinanç 1934'ten aktaran, Şatıroğlu 2010: 16).

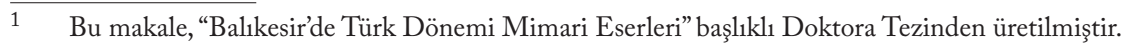


Karesi Bey, kendi ismiyle anılan beyliğinin sınırlarını, Sarı Saltuk'un adamlarından faydalanarak daha da genişletmiştir. Karesi Beyliği, merkezi ilan ettiği Balıkesir'den başka Bergama, Ayvacık, Altınova, Edremit, Burhaniye, Bayramiç, İvrindi, Ezine, Susurluk, Bigadiç ve Sındırgı yerleşim yerlerine de sahiptir (Uzunçarş1lı 1925:74; Mutaf 2003:6).

Karesioğlu Süleyman Bey 1357'de Trova hakimi olmuş, Kemer Edremit, Edremit ve körfezin kuzeyinde Çanakkale boğazına kadar olan kısım ise 1357'den sonra Osmanlıların eline geçmiştir. Osmanlı kayıtlarında Karesi Beyliği'nin ilhakı ile ilgili 1334, 1336, 1349, 1354 gibi muhtelif tarihler verilmektedir (Uzunçarş1lı 1988: 98).

Osmanlı Devleti, Karesi Beyliği’nin hakimiyetine katılımıyla büyük bir güce kavuşmuştur. Zira bu beylik denizcilik alanında büyük bir birikime sahiptir. Karesi Beyliği'nin ileri gelen komutanlarından Evrenos Bey, Hacı İlbey, Ece Halil Bey ve Gazi Fazıl Bey'in askeri bilgi ve yeteneklerinden istifade etmişlerdir (İnalcık 2005:29). Karesioğulları Beyliği’nin 14. yüzyıl ortalarında Osmanlılar tarafından ortadan kaldırılmasıyla, Osmanlıların kısa süre içerisinde Batı'da, özellikle Rumeli'de fetih hareketlerine başlayarak genişlemesi mümkün olabilmiştir. Osmanlı Beyliği Rumeli’ye Karesi Beyliği’nin gemileriyle geçmiştir (Emecen 2003'ten aktaran, Şatıroğlu 2010: 29).

Karesi sancağ1 olarak anılan bölgeye 17.yüzyıl sonlarında çok sayıda Yörük, Çepni ve Türkmen yerleşmiştir. Eski Manyas civarı da yoğun Çepni göçlerinden nasibini almıştır (Su 1938: 54; Kadıŏlu 1935: 23).

Karesi sancağı 1841 y1lında Hüdavendigar Eyaletine bağlanmıştır. 1864 y1lına kadar Karesi sancağının Erdek kazasına bağlı nahiye müdürlüğü olan Manyas 1879 yılında Bandırma'ya bağlı bir nahiye yapılmış ve bu tarihten sonra da hep bu durumda kalmıştır (Mutaf 2003: 118). 1877-78 yıllarındaki Osmanlı - Rus savaşı sonrası Rusların eline geçen Kafkasyadan gelen insanlar, Balıkesir'in çeşitli yerlerinde iskân edilmiştir. Eski Manyas bölgesine Kırım'dan gelen Türkler yerleştirilmiştir (Mutaf 2003: 16; Su 1938: 56). 


\section{Kaynak ve Araştırmalar}

Eski Manyas'ın tarihi coğrafyası ile ilgili çalışmalar bulunurken² Ortaçağ ve Türk Dönemine ait mimari yapıları inceleyen bilimsel çalışmalar çok kısıtlıdır. Bunlardan erken tarihli bir çalı̧̧ma; Franz Taeschner'in çalışmasıdır (Taeschner 1962: 354). Zaviyeli camiden bahseden bir diğer çalışma Semavi Eyice tarafından kaleme alınan makaledir (Eyice 1963:34). Zeynep Mercangöz'ün "Bizans'ın Son Yıllarında Balıkesir Yöresi” adlı makalesinde Balıkesir'deki kaleler hakkında önemli bilgiler sunulmaktadır (Mercangöz 2005: 46).

Günümüze daha yakın tarihlerde hazırlanan doktora (Sözlü 2014: 81) ve yüksek lisans (Şatıroğlu 2010: 45) tezlerinde Eski Manyas'taki yapılar ele alınmı̧̧tır. Şatıroğlu tarafından hazırlanan yüksek lisans tezi mimari yapılarla birlikte bölgenin tarihi coğrafyasını da ele almıştır. Yukarıda bahsedilen çalışmalar dışında, bölgedeki yapıları inceleyen yayımlanmış bir çalışma bulunmamaktadır.

\section{CAMi}

\section{Tarihlendirme}

F. Taeschner çalışmasında caminin 1336 yılından az sonraya ait olduğunu öne sürmekte ve bu varsayımın doğru çıkması halinde bu caminin en eski Osman1 yapıları arasında yer alacağını söylemektedir. Eyice; Taeschner'in görüşüne karşı çıkmakta ve Karesi Beyliği'nin 1336-37'de sona ermesi sırasında bu caminin inşaatının tamamlanmadan bırakıldığını iddia etmektedir. Eyice'ye göre, bu da XIV. yüzyıla ait bir Osmanlı eseridir.

Yapı üzerinde kesin tarih veren herhangi bir kitabe bulunmadığından tarihlendirme yapmak güçtür. Ancak yapının göstermiş olduğu zaviyeli plan ve

2 Manyas ve Eski Manyas tarihiyle ilgili detaylı bilgi için bkz.: J. A. Cramer, Geographical and Historical. Description of Asia Minor, Oxford, 1831, s. 54-58.; İsmail Hakkı Uzunçarşıll, Yayına Hazırlayan: Abdülmecit Mutaf, Kares, s.- $i$ Vilayeti Tarihşesi, Balıkesir, 2000, s. 57; Hikmet Aydın, Balıkesir, Balya, Ilıca, Şaml Yöreleri, Balıkesir, 1999; Tacettin Akkuş, Gönen ve Köyleri Tariḩ̧esi, İstanbul, 2010; Kerim Kani Akpınarlı, Balıkesir Şehir ve Belediye Taribi, Balıkesir, 2009; Anonim, Balıkesir Bir Kent Kimliğgi, Ankara, 1997; Anonim, Bitek Kent Balkesir, Belirsiz, 2003; J. Arthur - R. Munro, "Inscriptions From Mysia", The Journal of Hellenic Studies, JSTOR, Vol. 17, 1897; Ekrem Çavuldur, "Balıkesir Tarihçesiyle İlgili Eski Bir Vesika", Kaynak Dergisi, Balıkesir, 1937; Abdülmecit Mutaf, Salnamelere Göre Karesi (1847-1922), Balıkesir, 2003, Abdülmecit Mutaf, Taribi Eserleriyle Balkkesir, Balıkesir, 2003; Annuaire Oriental, "Balıkesser", De L'orient Fonde en 1880, Commerce, Industrie Administration, Magistrature, Constantinople, 1913, Halil Polat, 751 No'lu Ballkesir Şer'iyye Sicil Defterine Göre Balıesir'in Sosyal, Hukuki ve Dini Yapisi (H.1269-1272/M.1854-1857), (Süleyman Demirel Üniversitesi Sosyal Bilimler Enstitüsü Yayımlanmamış Yüksek Lisans Tezi), Isparta, 2003; Nahide Şimşir, Balıkesir Şehri ve Taribi Araştırmaları, İstanbul, 2013; Halil Sözlü, Balıkesir'de Türk Dönemi Mimari Eserleri, (Van Yüzüncü Yıl Üniversitesi Sosyal Bilimler Enstitüsü Yayımlanmamı̧ Doktora Tezi), Van, 2014. 
mimari özellikleri dikkate alındığında Erken Dönem Osmanlı özelliklerini bünyesinde barındırdığı görülmektedir. Buradan hareketle bizce de yapıyı, Semavi Eyice'nin yapmış olduğu XIV. yüzyıla tarihlendirilmek mümkündür.

\section{Mimari Tasvir}

Eski Manyas harabelerinde bulunan yapı yüksek bir tepe üzerine inşa edilmiştir. Bir kısmı yıkılmış olan caminin kuzeyinde bir türbe bulunmaktadır (Fotoğraf-1).Zaviyeli, camiler grubunda olup, caminin yan mekânları büyük oranda yıkılmış vaziyettedir. Ana eksende peş peşe sıralanmış iki kubbeli bölüm, ilk bölümün doğusunda ve batısında ise yan mekanlar yer almaktadır. Bu iki kubbeli bölümden güneydeki, asıl ibadet mekanı olarak değerlendirilmiştir. Orta bölüm dıştan, yaklaşık olarak 14.26 x $7.12 \mathrm{~m}$, içten 12.66 x $5.52 \mathrm{~m}$ ölçülerinde kuzey-güney yönünde dikdörtgen bir plan göstermektedir (Çizim-1-2).

Cami cephelerinin büyük kısmı tahrip olmuş durumdadır. Asıl ibadet mekânının güney ve batı cephesi daha sağlam olarak günümüze gelebilmiştir. Ayrıca doğudaki yan mekânın doğu, kuzey ve güney duvarının bir kısmı ayaktadır. Duvar kalıntılarından anlaşıldı̆̆ kadarıyla, duvarların birbirine paralel olarak yerleştirilmiş iki sıra ahşap hatılla desteklendiği anlaşılmaktadır.

Yapının üst örtüsü yıkılmış durumdadır. Güneydeki asıl ibadet bölümünün batı duvarının üst kısmıyla doğu mekanın kuzey cephesinin üst kısmında çok az bir bölümü kalmış olan, tuğlalarla oluşturulmuş tek sıra testere dişi motifinin varlığı yapının ilk hali hakkında fikir vermektedir. Cephelerde herhangi bir süsleme unsuruna yer verilmemiştir. Zaviyeli yapının minaresi olduğuna dair bir iz bulunamamıştır (Fotoğraf-2).

Camiye girişin, kalıntılardan hareketle kuzey cephede olduğu düşünülmektedir. İç mekânı üst örtünün yıkıntıları doldurmuş durumdadır. Peş peşe iki kubbenin oluşturduğu bölümde kuzeydeki kubbeli bölümden asıl ibadet mekanına geçiş büyük ihtimalle, yan mekanlı camilerde yaygın olarak karşımıza çıkan birkaç basamak ve geniş bir kemer açıklığıyla yapılmıştır. Buradan batıdaki yan mekâna geçiş, mekânın kuzeybatı köşesine açılan kapıyla sağlanmaktadır. Simetriğinde de doğudaki yan mekâna geçişi sağlayan açıklık olmalıydı fakat günümüzde yıkık durumdadır. Kuzeydeki kubbeli olduğunu düşündüğümüz mekânın doğu ve batı duvarlarında da güneydeki mekânda olduğu gibi kemerlerin varlığı kalıntılardan anlaşılmaktadır. 
Asıl ibadet mekânı, kuzey güney doğrultusunda dikdörtgen bir plana sahip ve beden duvarları örtü sistemine kadar yıkılmadan günümüze gelebilmiştir. Mekânın üzeri kubbe ile örtülüdür. Kubbeye geçişler mukarnas dolgulu pandantiflerle sağlanırken, doğudaki yan mekânda kubbeye geçiş Türk üçgenleriyle sağlanmıştır. Kubbenin dilimli olduğunu kalan izler bize göstermektedir. Güneydeki bölümün üst örtüsüne ait kalan izlere dikkatli bakıldığında, beden duvarları yüzeyinde hissedilen sivri kemerlerin hemen üzerinde başlayan testere dişi şeklindeki motiflerin başlattığ 1 bir dilimlenmenin, kubbenin içine doğru devam ettiği anlaşılmaktadır. Sivri kemerin altında da pencerelere yer verilmiştir. Güney duvarda bu kemeri mihrabın bordürü kesmektedir. Aynı kemerin doğu duvarında da olduğu güneydoğu köşedeki kemer kalıntısından anlaşılmaktadır.

Kıble duvarı ortasındaki mihrap, sağlam vaziyette olup dikdörtgen bir çerçeve içerisinde, yarım daire planlı ve mukarnas kavsaralıdır. Üç yönden bordürle çevrili olduğu, tuğlaların daha derinde kalmış olmasından anlaşılmaktadır. Mihrabın en dıştaki geniş bordürünün üst iki köşesinde birer kabara olduğuna kalan boşluklar işaret eder. Tuğla malzemeden yapılmış olan mihrabın ilk halinin alçı sıvalı olduğu düşünülmektedir (Fotoğraf-3).

Doğudaki yan mekân içten 5.38x5.38 m ölçülerinde kare planlı olup, $0.80 \mathrm{~m}$ kalınlığındaki duvarlarının büyük bölümü ve kubbesi yıkılmış durumdadır. Kubbeye geçişlerin Türk üçgenleriyle sağlandığı kalan izlerden görülebilmektedir (Fotoğraf-4). Mekânın batı duvarı üst örtü seviyesine kadar günümüze sağlam ulaşabilmişken, güney ve kuzey duvarları büyük oranda yıkılmış vaziyettedir. Doğuda ise zemin seviyesinde duvar izleri görülebilmektedir. Batı duvarı yüzeyinde sıva izlerine rastlanılmaktadır.

Batıdaki yan mekânın ise doğu duvarı günümüze kadar ulaşabilmiştir. Bu bölümün doğu duvarının uzunluğu 4.00 m olduğuna göre, mekanın 4.00x4.00 m ölçülerinde kare planlı olması akla yatkın gelmektedir. Kubbeyle örtülü olduğu düşünülen mekânda örtüye geçişin diğer yan mekânda olduğu gibi Türk üçgenleriyle sağlandığı kalan izlerden belirlenmektedir. Duvar kalınlığı 0.80 m'dir.

Yapının içinde minbere veya minber kalıntısına rastlanılmamıştır.

Zaviyeli plan tipine sahip olan yapıda, benzer örneklerinde de sık görülen taş ve tuğla malzemenin harçla birlikte kullanıldığı görülmektedir. Kısmen beden duvarlarında mermerden devşirme malzeme de kullanılmıştır. Kullanılan taşlar kaba yonu taşlardan oluşmaktadır. Duvar örgüsünde, kaba yonu taşların etrafına 
tuğlalar yerleştirilmiştir. Kemerlerde, mihrapta, pencerelerde, örtü sisteminde ve örtü sistemine geçişte tuğla malzemenin kullanıldığ görülmektedir.

Doğu yan mekânın duvar yüzeyindeki izlerinden duvar yüzeylerinin sıvalı olduğu ve kubbeye geçiş ögesine kadar olan kısımda kaba yonu taşın daha çok kullanıldığı görülmektedir.

Devşirme olarak belirttiğimiz mermerler daha çok cephelerde beden duvarlarının alt seviyelerinde kullanılmıştır. Kuzey duvarın doğu bölümünün alt köşesindeki devşirme mermer blokta "EKT $\Omega$ ” yazısının (Şatıroğlu 2010:76) olduğu görülmektedir.

\section{TÜRBE}

\section{Tarihlendirme}

Türbe, Eski Manyas Camii'nin yaklaşık 20 m kuzeyinde yer almaktadır. Yap1 üzerinde tarihini belirtecek herhangi bir kitabeye rastlanmamıştır. Plan anlayışı, kullanılan malzeme ve teknikten hareketle yapıyı XIV. - XV. yüzyıla tarihlendirebiliriz. Yapı günümüzde kısmen yıkılmış durumdadır (Fotoğraf-5).

\section{Mimari Tasvir}

Eğimli bir arazi üzerine kurulan türbe, camiye göre biraz daha sağlam bir şekilde günümüze gelebilmiş ve beden duvarları ile üst örtüde kısmen yıkılmalar olmuştur. Yapı dıştan 7.80 x 7.80 m, içten 5.60 x 5.60 m ölçülerinde olup, kare planlı ve kubbe ile örtülüdür. Kubbe sekizgen kasnak üzerine oturmaktadır. Kasnak beden duvarından daha içeride yer alır. Kasnak duvarının kirpi saçakla sonlandığı görülmektedir (Çizim-3).

Türbenin cephelerinde taş ve tuğla malzemenin kullanılmasıyla oluşturulan almaşık duvar tekniği görülmektedir. Beden duvarı alt seviyesinde iki sıra taş üç sıra tuğla, üst seviyede üç sıra taş üç sıra tuğla kullanımıyla almaşık teknik oluşturulmuştur.

Doğu cephede türbeye giriş kapısı bulunmaktadır. Kapı kemer kilit taşı üzerinden kubbe kasnağına kadar cephede ayrılma oluşmuştur (Fotoğraf-6). Kuzey cephe ortasında, sivri kemerli bir pencere açıklığı olduğu kalan izlerden anlaşılmaktadır. Yine bu cephede de kemer kilit taşı üstünde ayrılma meydana gelmiş olup yıkılmak üzeredir.

Batı cephede de kuzeydeki cephe anlayışı görülmektedir. Cephenin kuzey ucu güney ucuna oranla daha alçakta kalmaktadır. Bu cephedeki tahribat di- 
ğer cephelere oranla daha fazladır. Cephe ortadan ikiye bölünmüş gibi görünmektedir. Güney cephenin köşeleri yıkılmış durumdadır. Yine bu cephenin ortasında, beden duvarı ve kasnakta çatlama görülmektedir (Fotoğraf-7). Türbenin tüm cephelerinde kirpi saçak uygulaması vardır.

Türbenin inşasında kaba yonu taş ve tuğla malzeme birlikte kullanılmıştır. Tuğlalar kaba yonu taşların arasına yatay ve dikey olarak da yerleştirilerek kasetleme tekniğinde örülmüştür. Camide olduğu gibi burada da pencere kemerlerinde, kapıda ve örtüde tamamen tuğla kullanılmıştır. Türbenin cephelerinde almaşık duvar tekniği uygulanmıştır. Kubbenin içten sıvalı olduğu tuğlalar üzerindeki sıva kalıntılarından anlaşılmaktadır. İç mekânda yaklaşık 1.50 m yüksekliğe kadar kaba yonu taşların kullanıldığı, üzerinde ise tuğla malzemenin varlığ1 dikkat çekmektedir (Fotoğraf-8). Türbede cenazelik kat1 bulunmamaktadır. 


\section{DEĞERLENDİRME VE SONUÇ}

"Zaviyeli" veya "Eyvanlı" camiler olarak isimlendirilen yapılar, Beylikler devrinin, özellikle Osmanlılarda geliştirilen en yaygın ve yeni cami tipidir. Bu camiler plan olarak Selçuklu devrinin kapalı avlulu medreselerini hatırlatırlar. Sayıları değişen dervişlerin barınması, ibadet veya din dersleri için kullanıldıkları kabul edilen, kubbeli ve tonozlu tabhane odaları vardır. Kıble önünde ana eyvan yan eyvanlar olmak üzere sayıları birden üçe kadar değişen eyvanları olduğundan "eyvanlı camiler" olarak da isimlendirilirler. Bazı yapılarda bu eyvanlar sonradan açılmıştır. Ana eyvan ve orta mekân bu camilerin ana bölümünü teşkil eder (Öney 1989: 14).

Bu tip binalar esas itibariyle bilhassa erken misallerde aynı aks üzerinde birbirini takip eden her biri bir kubbe ile örtülü iki ayrı mekândan ve bunlardan cümle kapısı tarafında olanın iki yanına bitişik yine kubbeli (nadir hallerde tonozlu) küçük hücrelerden meydana gelir. Yalnız geç devirlere doğru, büyük kubbeli mekânlardan birincisinden vazgeçilmeye başlandığı görülür (Eyice 1963: 5).

Erken Osmanlı dinsel yapıları içinde değişik amaçları içeren bir yapı tipi uzun yıllar kullanılmış, bir bakıma kuruluş ve gelişme devrinin simgesi niteliğine bürünmüştür. Zaviyeli - Tabhaneli camiler olarak adlandırılan bu yapıların örnekleri bütün Osmanlı topraklarında değişik yoğunlukta uygulanmışlardır. Kendi içlerinde sınırlı da olsa belirli bir değişikliği getiren bu yapılar, aynı zamanda Osmanlı toplum yapısının XIV ve XV. yüzyıldaki durumu konusunda da ilginç kesit vermektedir. Bu yüzyılda tarikatların toplum yapısında oynadıkları rol göz önüne alınınca bu tür yapıların hangi gereksinmenin sonucu ortaya çıktığını açıklamak kolaylaşmaktadır. Dinsel görevi yerine getiren caminin yanı sıra oturulacak, içinde yaşanacak mekânları da içeren bu yapılar, Osmanlı sultanlarının politik amaçlarına da uygun bir biçimlenmeye konu olmuşlardır. XII. ve XIII. yüzyıl medrese ve zaviyelerinin planlama anlayı̧̧ı bu yapılarda etkilerini sürdürmüş, zamanla yeni boyutlar kazanmıştır. Kaynak yine Anadolu'da değişik amaçlı yapılarda karşılaştığımız avlulu, dört eyvanlı şemadır (Sözen 1976:51-52).

Günümüze üst örtüsü ve beden duvarlarının bir kısmı yıkık vaziyette ulaşan yapının, yan mekânlardan doğudakinin üst örtüsü ve beden duvarının yarısı, batıdakinin ise tamamı yıkılmış durumdadır.

Eski Manyas Cami (Ç. 21) plan açısından, İznik Nilüfer Hatun İmareti (1388) (Eyice 1963: 33), İznik Yakup Çelebi Zaviyesi (1389) (Eyice 1963: 
33), Geyve İmareti (14.yy) (Eyice 1963: 34) ile birlikte bütün birimlerinin üst örtüsünün kubbe olması bakımından Bursa Muradiye Cami (1425-26) (Eyice 1963: 38; Aslanapa 2004: 56; Ayverdi 1972:305), Amasya Yörgüç Paşa İmareti (1428) (Öney 1989: 14; Aslanapa 2004:64), Edirne II. Murad Zaviyesi (1435-36) (Eyice 1963: 39), Ankara İmaret Cami (1444) (Eyice 1963: 41; Tüfekçioğlu 2001: 244: Aslanapa 2004:71-72; Aslanoğlu 1998: 7; Öney 1971: 60), Bursa Karacabey İmareti (1456)(Eyice 1963: 41; Tüfekçioğlu 2001: 306), Bursa Hamza Bey Cami (1461)(Eyice 1963: 42) gibi yapilarla aynı özelliklere sahiptir.

Eski Manyas Cami'nde mihrap bölümünü örten kubbeye geçişler mukarnas dolgulu pandantifle sağlanmıştır. Yan mekanlı camiler grubuna giren Filibe Şehabeddin Paşa Cami’nin (1444) mihrap bölümü kubbesinde de aynı özellik görülmektedir.

Mihrap bölümü kubbesinin dilimli olması bakımından, Üsküp Alaca İshak Bey Cami (1438) orta kubbesiyle ve Bursa Yeşil Cami (1424) yan mekanıyla eş değer özelliğe sahip olduğu anlaşılmaktadır. Ancak incelemiş olduğumuz caminin mihrap bölümünü örten kubbenin dilimli olması önemli bir özellik olarak gösterilebilir. Bu tür yan mekanlı yapılarda mihrap bölümünün dilimli kubbeyle örtülü olduğu tek örnek olarak söylenebilir.

Eski Manyas Cami doğu yan mekanındaki kubbe Türk üçgenleri üzerine oturması özelliği, Edirne Muradiye Camii'nin (1426) mihrap bölümü kubbesinde ve Bursa Yeşil Cami kubbelerinde de görülmektedir.

Beden duvarlarında görülen kaba yonu taşların tuğlalar kullanılarak bir çerçeve içine alınması Bursa Muradiye Camii (1426) beden duvarlarında da uygulanmıştır. Öte yandan almaşık duvar erken dönemde birçok yapıda uygulanan bir tekniktir.

Eski Manyas'taki türbe, günümüze ilk hâliyle gelmiştir. Kare planlı türbenin üzeri kubbe ile örtülüyken günümüzde kasnak kısmı sağlam kalabilmiştir. Beden duvarlarında geniş çatlaklar meydana gelen türbe ayakta kalabilmek için direnmektedir. Manyas Eski Türbe plan özelliği olarak İznik Kırkkızlar Türbesi (XIV.yy) (Daş 2007:25; Tuncer 1991:123; Ayverdi 1966:179-180), Bursa Çoban Bey Türbesi (XIV.yy) (Daş 2007:31; Ayverdi 1966: 104-105), Mustafakemalpaşa Lala Şahin Paşa Türbesi (XIV.yy sonu) (Daş 2007:39; Ayverdi 1966: 193-194; Tüfekçioğlu 2001:39) Bursa Gülçiçek Hatun Türbesi (1390 civarı) (Daş 2007:48; Önkal 1992:278) İznik Çandarlı Halil Hayreddin ve Ali Paşa Türbesi (1387) (Daş 2007:44; Tüfekçioğlu 2001:58; Ayver- 
di 1966:332-333; Goodwin 1971:21; Dorn 1941:80) Bursa I. Murad Türbesi (1389-1400) ile benzerlik göstermekle birlikte bu örnekler çoğaltılabilir.

Eski Manyas'taki türbe, kare prizmal tipte tromplarla geçilen kubbe ile örtülü tek katlı bir yapıdır. Türbe kare prizmal plan şeması ile Erken Osmanlı yapıları ile paralellik göstermektedir.

Klasik Osmanlı mimarisinde, Selçuklu türbelerinin bazı özellikleri yaşamaya devam ederken, bazı özellikler de yavaş yavaş ortadan kalkmıştır. Selçuklu döneminde en sık rastlanan sekizgen prizmal gövdeli türbenin yerini Erken Osmanlı Döneminde kare prizmal gövdeli türbeler almıştır.

Osmanlı dönemi dışında ise; Karamanoğulları döneminden Mut Küçük Türbe (14.yy sonu), Niğdde Gündoğdu Türbesi (1344) (Şatıroğlu 2010:133), Karaman İbrahim Bey Türbesi (1459-60) Erdemli’de Anonim Türbe (XV.yy), Erdemlide Sinan Bey Türbesi (1504-1514) kare prizmal gövdeli olmaları bakımından Eski Manyas'taki türbeyle benzer özelliklere sahip birkaç örnektir.

İncelenen türbede kubbeye geçiş ögesi olarak trompun kullanıldığı görülmektedir. Bu açıdan İznik Kırkkızlar Türbesi, Mustafa Kemalpaşa Lala Şahin Paşa Türbesi (1376), Bolu Gerede'de Şıh Dede Türbesi (XIV.yy sonu), Bilecik Sögüt'te İsa Dede Türbesi (XIV.yy), Gelibolu'da Şerbetçi Baba Türbesi (XIV.yy sonu 15.yy başı), Bursa Yıldırım Bayezid Türbesi (1406), Amasya Selamet Hatun Türbesi (XV.yy ilk yarıs1), Bursa II. Murad Türbesi (1451), Amasya Pir İlyas Türbesi (1482-1483), Tire Yağlığlu Türbesi (15.yy başları), Ankara Karacabey Türbesi (1444-45) ve Bursa Hamza Bey Türbesi (1461) (Daş 2007:331-334) örnek olarak verilebilir.

Eski Manyas'taki türbede almaşık duvar tekniği görülmesi bakımından, İznik Yakup Çelebi Türbesi (XIV.yy sonu), Gelibolu Mansur Bey Türbesi (XV.yy başı), bursa Yıldırım Bayezid Türbesi (1406), Tavşanlı Arslan Bey Türbesi (1432), Bursa Ebe Hatun Türbesi (1432-1481), Mustafa Kemalpaşa Ayaz Köyü Türbesi (1442), Ankara Karacabey Türbesi (1444-45) (Daş 2007:268269) ve Tire Rum Mehmet Paşa Türbesi (1472) (Önkal 1991:77-78; Tuncer 1991.241) verilebilecek örneklerden bazılarıdır.

Üzerinde herhangi bir kitabesi veya vakfiyesi olmayan türbe, kare prizmal planı, almaşık duvar tekniği ve yalancı kasnağın kullanılması Erken Dönem özelliklerini taşımaktadır.

Zaviyelerin toplumun sosyal yapısı üzerinde etkili olduğu bilinmektedir. İncelemiş olduğumuz zaviyeli bu caminin, yakın çevrede yaşayan göçebelerin Sünnileşmesinde önemli bir etkiye sahip olduğu düşünülmektedir. 
Eski Manyas Camii, zaviyeli/yan mekanlı camilerin erken örneklerinden önemli bir yapıdır. Eski Manyas, gerek ele aldığımız zaviyeli cami ve türbesiyle, gerekse bu yapıların karşısındaki tepe üzerinde inşa edilmiş olan Ortaçağ dönemine ait kale yapısıyla önemli ve dikkat çekilmesi gereken bir bölgedir. Caminin mevcut durumu incelenerek, ortada peş peşe iki kubbe, yan mekanlarında kubbe ile örtülü olduğu anlaşılmıştır. Bu değerlendirmeler neticesinde yapının restitüsyona yönelik çizimi de yapılmıştır (Çizim-4). Cami ve türbe ile ilgili bilinmeyen birçok sorunun cevabı arkeolojik çalı̧̧malara muhtaçtır. Bu münasebetle buradaki yapıların korunması, onarılması ve yaşatılması yegane temennimizdir. 


\section{KAYNAKLAR}

AKKUŞ, Tacettin (2010). Gönen ve Köyleri Tarihçesi, İstanbul, MVT Yayıncilik.

AKPINARLI, Kerim Kâni (2009). Balıkesir Şehir ve Belediye Taribi, Balıkesir, Balıkesir Belediyesi Kent Arşivi Yayınları.

ANONIM (1997). Balıkesir Rebberi (1920), Balıkesir Valiliği Kültür Yayınları 1997/1, Balıkesir.

ANONIM (2003). Bitek Kent Balıkesir, Balıkesir, Yapı Kredi Yayınları.

ASLANAPA, Oktay (2004). Osmanl Devri Mimarisi, Istanbul, İnkılap Yayınları.

AYVERDİ, Ekrem Hakkı (1966). Osmanlı Mimarisinin İlk Devri, C.I, İstanbul, Baha Matbaasi.

CRAMER, J. A. (1831). Geographical and Historical. Description of Asia Minor, Oxford.

DAŞ, Ertan (2007). Erken Dönem Osmanl Türbeleri, İstanbul, Gökkubbe Yayınları.

OTTO DORN, Katharina (1941). Das Islamısche Iznik, Berlin.

EREN, Muharrem (1990). Balıkesir'de Taribi Kitabeler, Balıkesir, Ince Ofset.

EYICE, Semavi (1963). "Zaviyeler ve Zaviyeli Camiler", İktisat Fakültesi Mecmuası, İstanbul, s. 3-80, Sermet Matbaası.

GOODWIN, Godfrey (1971). A. History of Ottoman Architecture, London, Thames and Hudson Ltd.

INALCIK, Halil (2005). "Batı Anadolu'da Yükselen Denizci Gazi Beylikleri, Bizans ve Haçlılar”, Uluslararası Batı Anadolu Beylikleri Sempozyumu Bildirileri 18-20 Ekim 2004, Balıkesir, s. 29.

KADIOĞLU, İsmail Hakkı (1935). Çepniler Balıkesir'de, Balıkesir, Vilayet Matbaası.

MERCANGÖZ,Zeynep (2005). “Bizans'ın Son Yıllarında Balıkesir Yöresi”, Uluslararası Batı Anadolu Beylikleri Sempozyumu 18-20 Ekim 2004, s. 4672, Balıkesir Üniversitesi Yayınları

MUTAF, Abdülmecit (2000). Karesi Vilayeti Tariḩ̧esi, Balıkesir, Zağnos Kültür ve Eğitim Vakfı Yayınları. 
, Abdülmecit (2003) Salnamelere Göre Karesi (1847-1922), Balıkesir, Zağnos Kültür ve Eğitim Vakfı Yayınları.

, Abdülmecit (2003). Taribi Eserleriyle Balıkesir, Balıkesir, Balıkesir Belediyesi Kültür Yayınları.

ÖNEY, Gönül (1989). Beylikler Devri Sanatı XIV-XV. Yüzy1l (1300 - 1453), Ankara, Türk Tarih Kurumu Basımevi.

ÖNKAL, Hakkı (1992). Osmanlı Hanedan Türbeleri, Ankara, Kültür Bakanlı̆̆ Yaymları.

ÖTÜKEN, S.Y1ldız (1988). “Karacabey İlçesindeki Tophisar Köyü’nün Ortaçağ'daki Önemi ve Tarihi Eserleri”, İzmir, Arkeoloji ve Sanat Taribi Dergisi IV, s. 89-106, Ege Üniversitesi Edebiyat Fakültesi Yayınları.

SÖZEN, Metin vd (1976). Türk Mimarisinin Gelişimi ve Mimar Sinan, İstanbul, 1976, Türkiye İş Bankası Kültür Yayınları.

SÖZLÜ, Halil (2014). Balıkesir'de Türk Dönemi Mimari Eserleri, (Van Yüzüncü Yıl Üniversitesi Sosyal Bilimler Enstitüsü Yayımlanmamış Doktora Tezi), Van.

SU, Kamil (1938). Balıkesir ve Civarında Türkmen ve Yörükler, İstanbul, Balıkesir Halkevi Yayınları.

ŞATIROĞLU, İlknur (2010). “Eski Manyas / Poimanenon Ortaçă̆ Yapıları” Hacettepe Üniversitesi Sosyal Bilimler Enstitüsü Yayımlanmamış Yüksek Lisans Tezi, Ankara.

ŞİMŞİR, Nahide (2013). Balıkesir Şehri ve Taribi Araştırmaları, İstanbul, IQ Kültür Sanat Yayıncılık.

TAESCHNER, Franz (1962). "Eski Manyas ve Harabeleri", Milletlerarası Birinci Türk Sanatları Kongresi, Ankara, s.352-355, Dil, Tarih ve Coğrafya Fakültesi Yayınları.

TUNCER, Orhan Cezmi (1991) Anadolu Kümbetleri II, Ankara.

TÜFEKÇİOĞLU,Abdülhamit (2001).Erken Dönem Osmanlı Mimarisinde Yazı, Ankara. Kültür Bakanlığı Yayınları.

UZUNÇARŞILI, İ. Hakkı (1988). Anadolu Beylikleri ve Akkoyunlu, Karakoyunlu Devletleri, Ankara. , İsmail Hakkı; Karesi Vilayeti Taribçesi, İstanbul, 1925. 
Fotoğraf-1. Eski Manyas Cami ve Türbenin Havadan Görünümü. (Google Earth 12.05.2020)

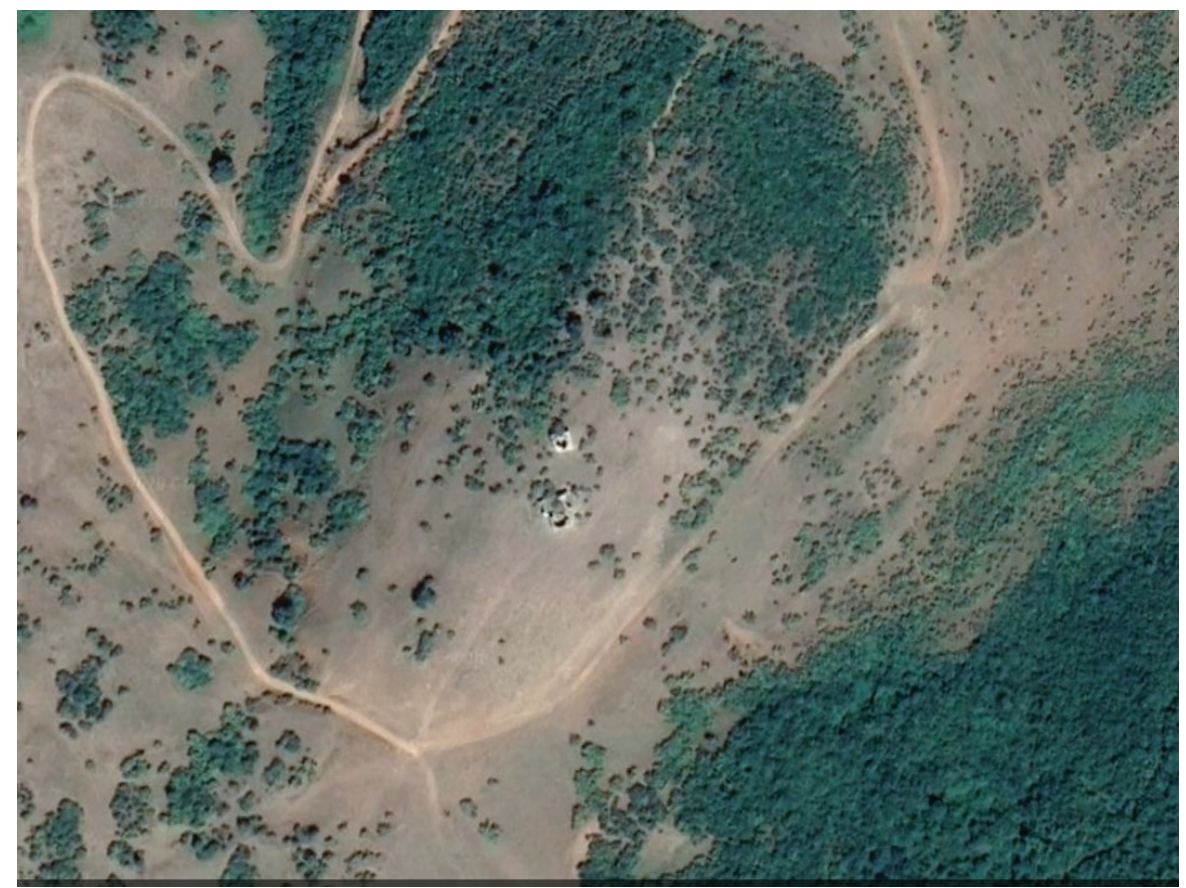


Çizim-1. Eski Manyas Cami ve Türbesi Vaziyet Planı
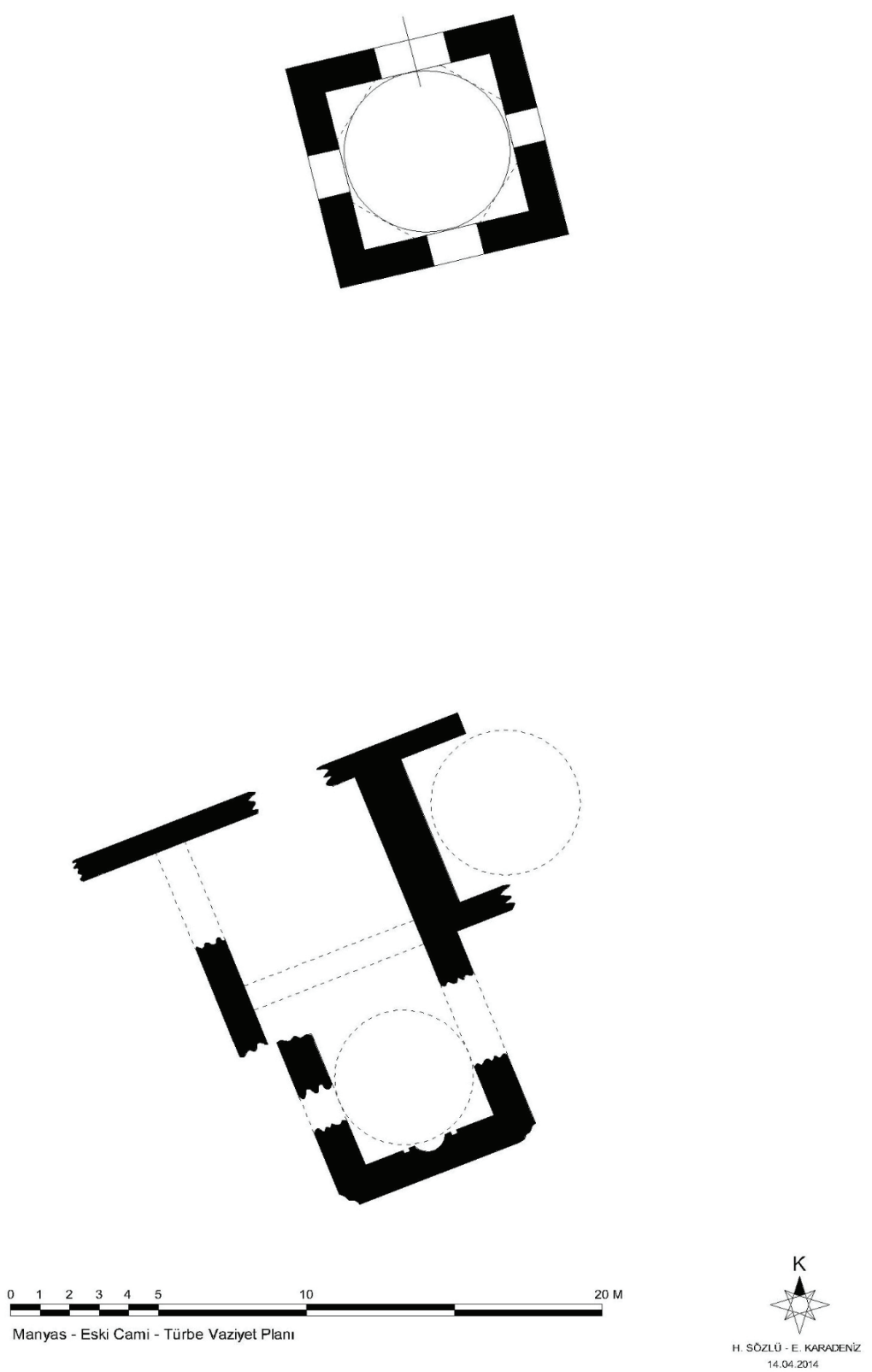
Çizim-2. Eski Manyas Cami planı.

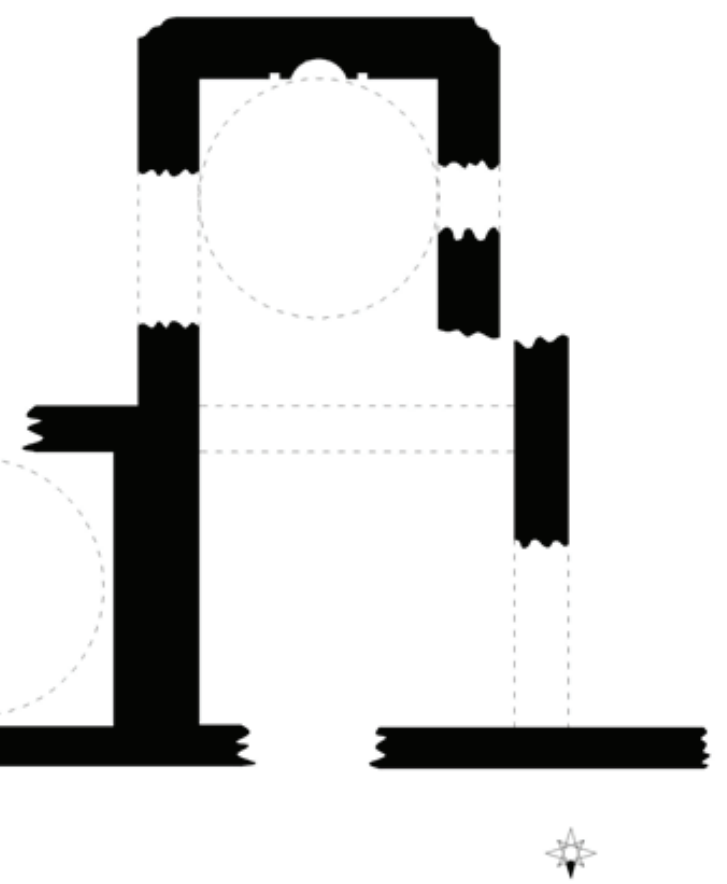

Çizim-3. Eski Manyas Türbe planı.

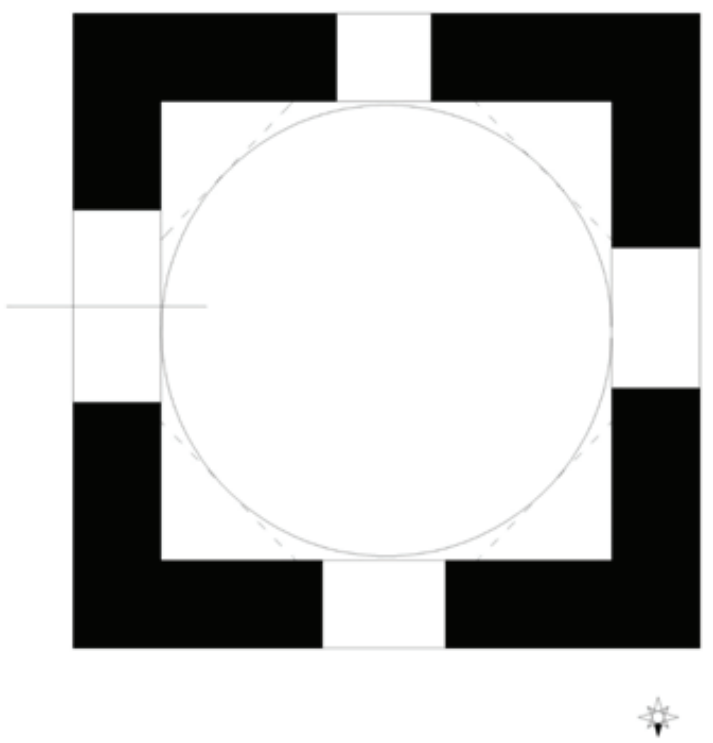


Çizim-4. Eski Manyas Cami Restitüsyon Planı

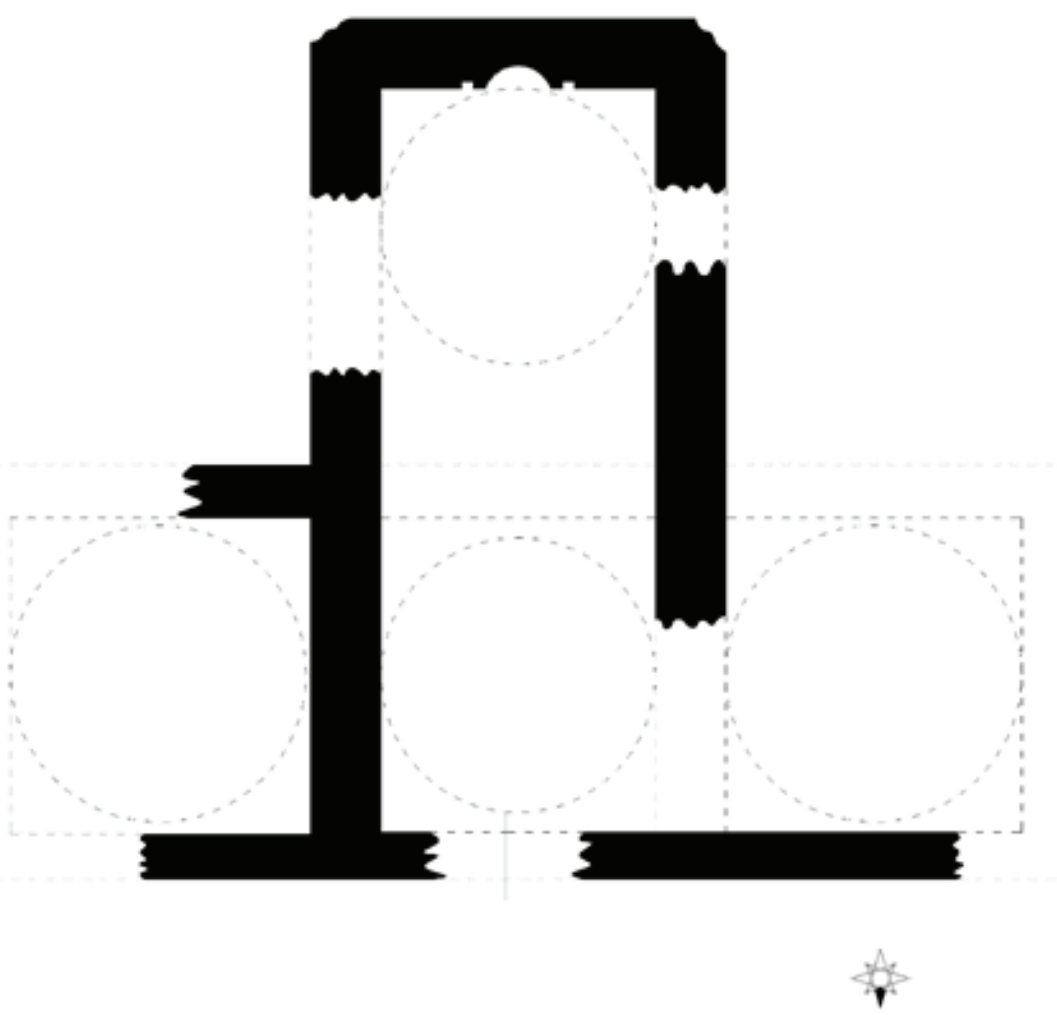


Fotoğraf-2. Eski Manyas Cami Genel Görünüm

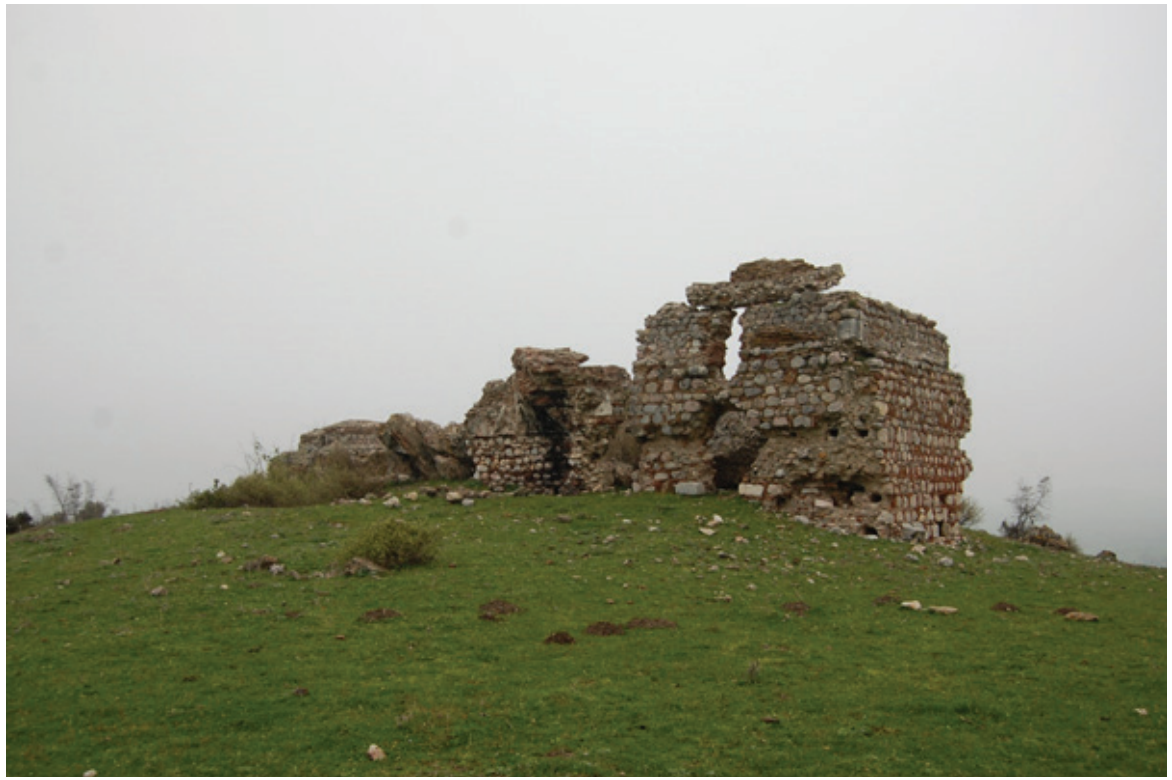

Fotoğraf-3. Eski Manyas Cami Kıble Duvarı

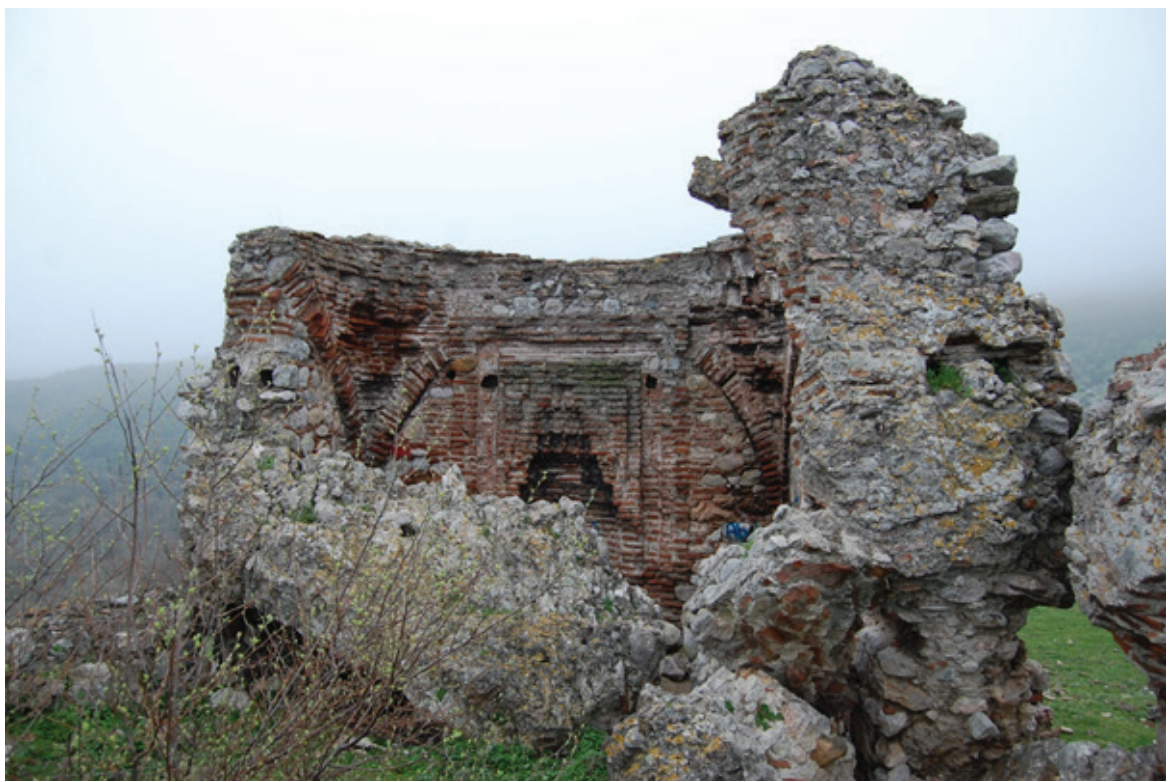


Fotoğraf-4. Eski Manyas Cami Mihrap Detay1

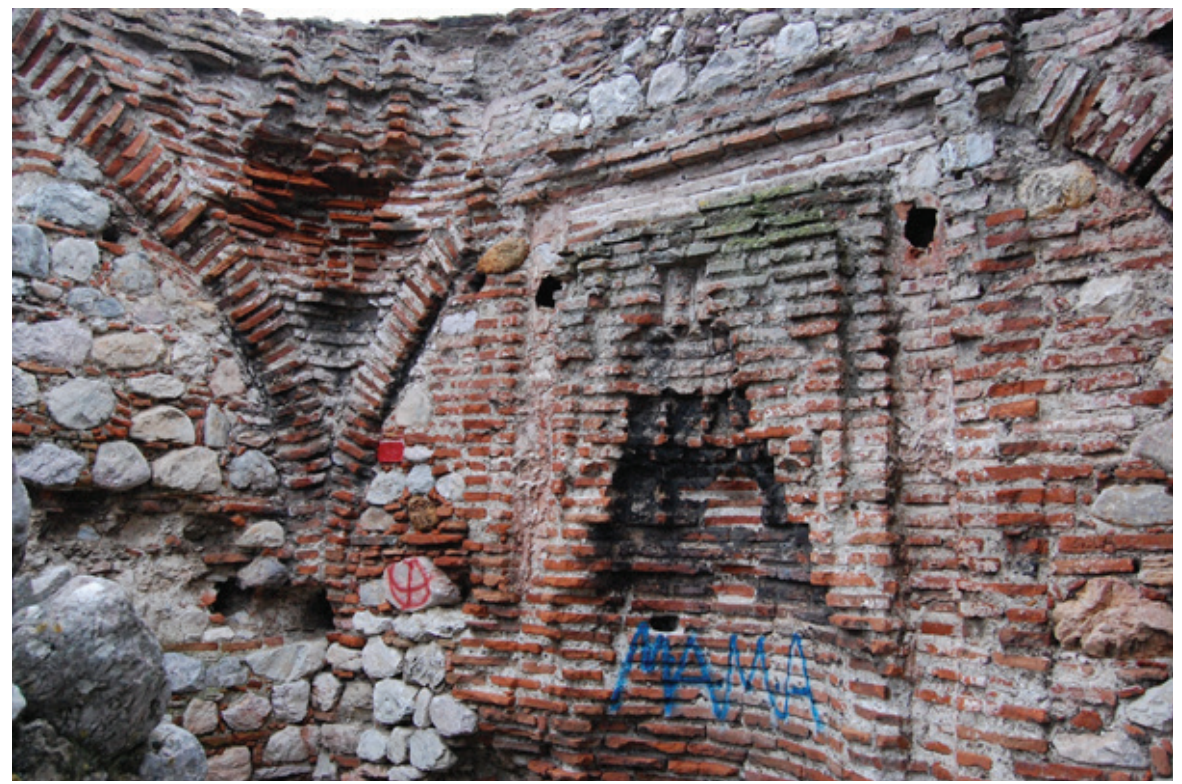

Fotoğraf-5. Eski Manyas Cami Doğu Yan Mekan Türk Üçgenleri

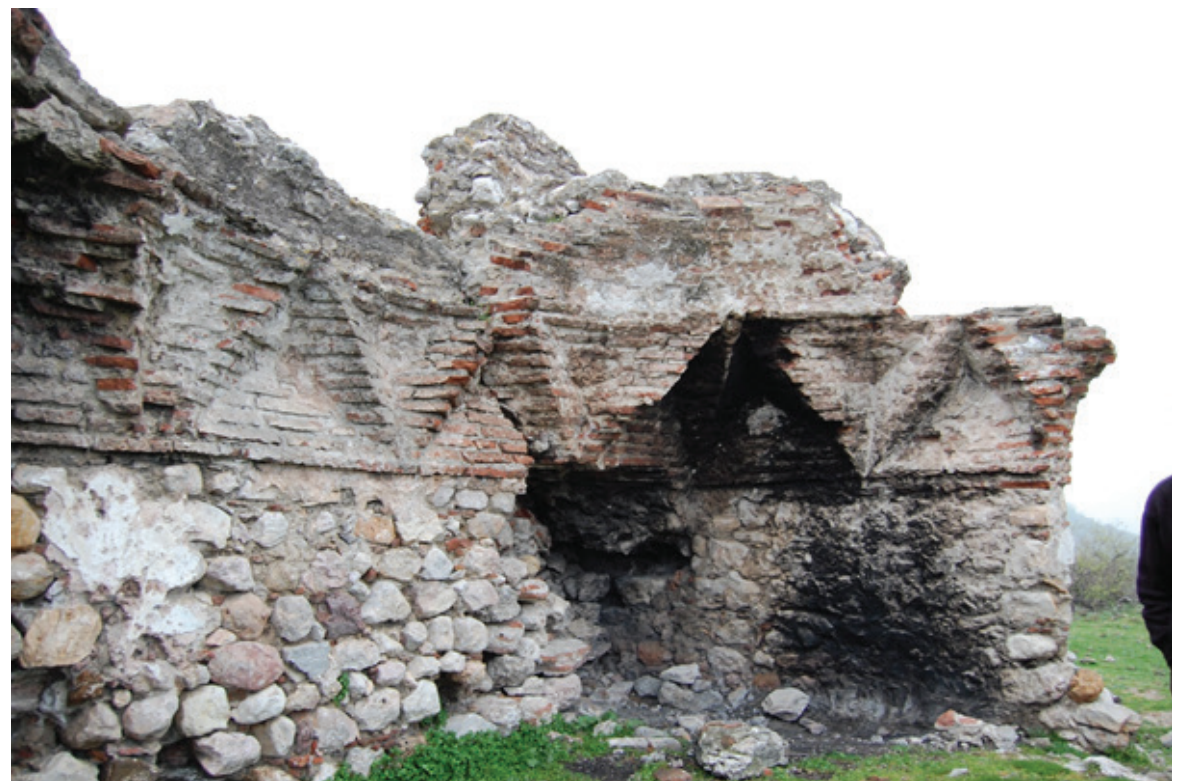


Fotoğraf-6. Eski Manyas Türbe Genel Görünüm

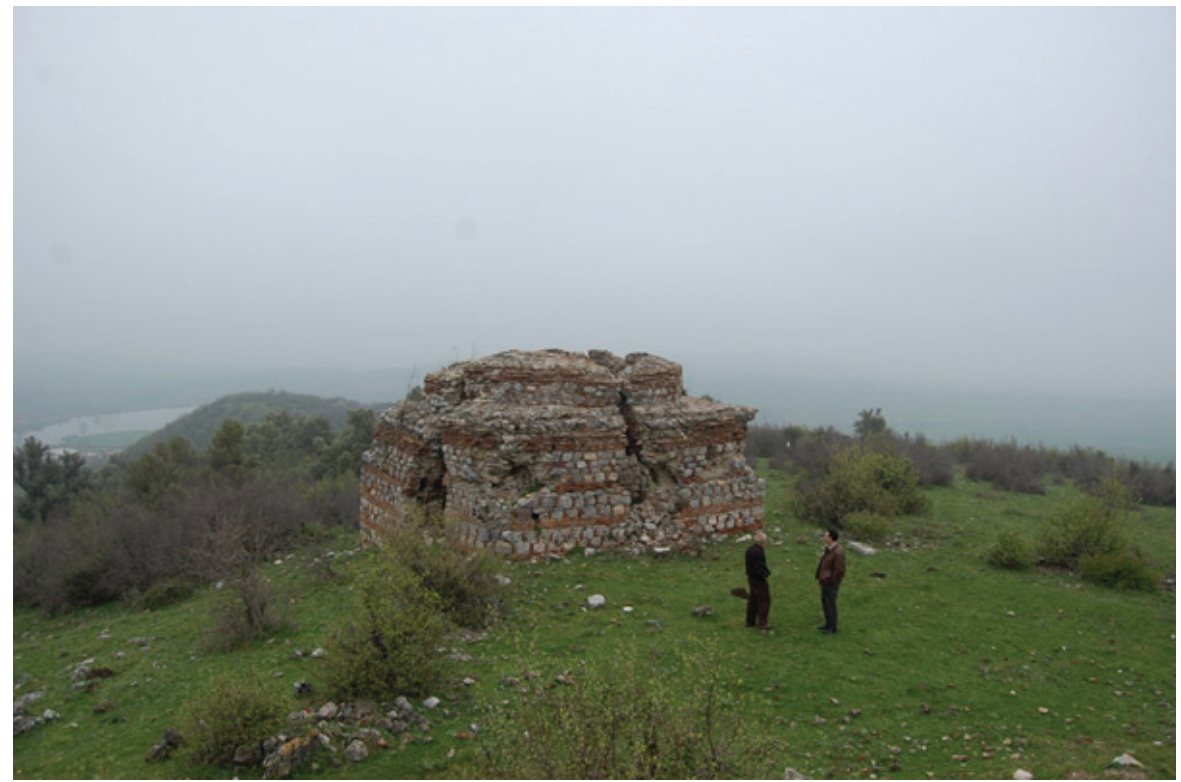

Fotoğraf-7. Eski Manyas Türbe Doğu Cephe

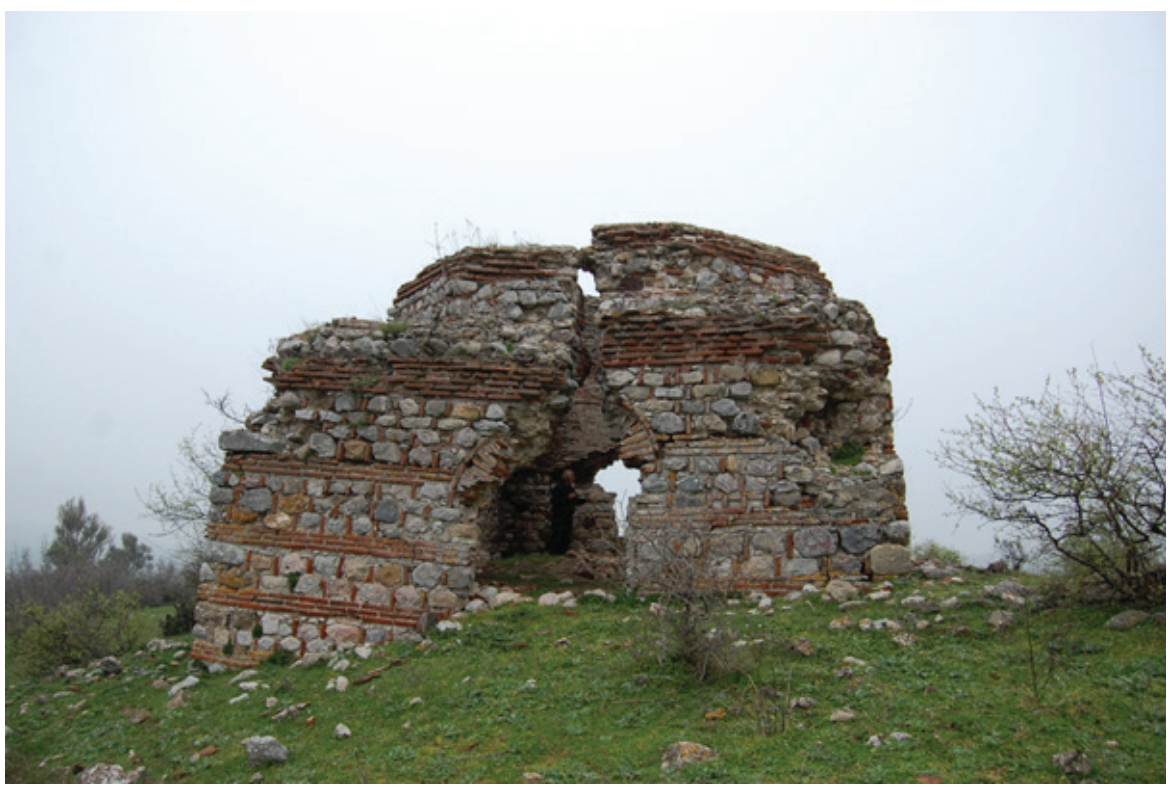


Fotoğraf-8. Eski Manyas Türbe İç Mekan Duvar Çatlakları

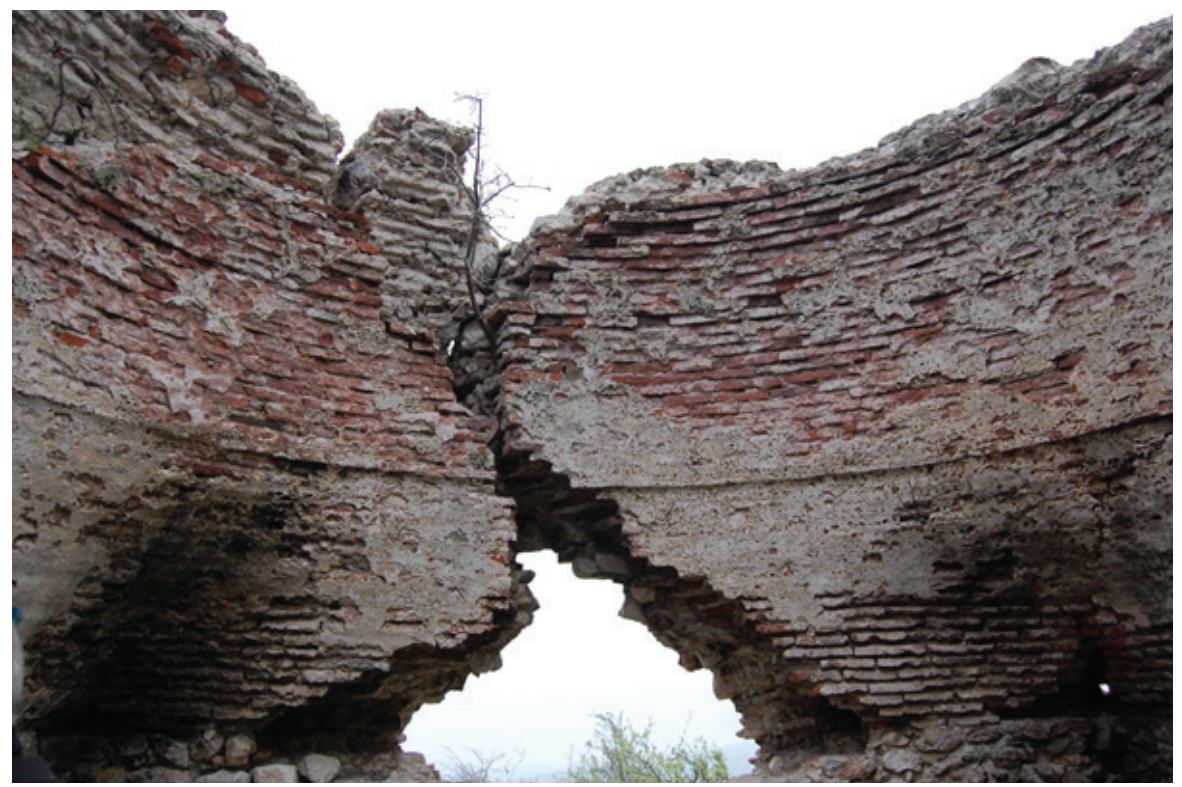

Fotoğraf-9. Eski Manyas Türbe İç Mekan

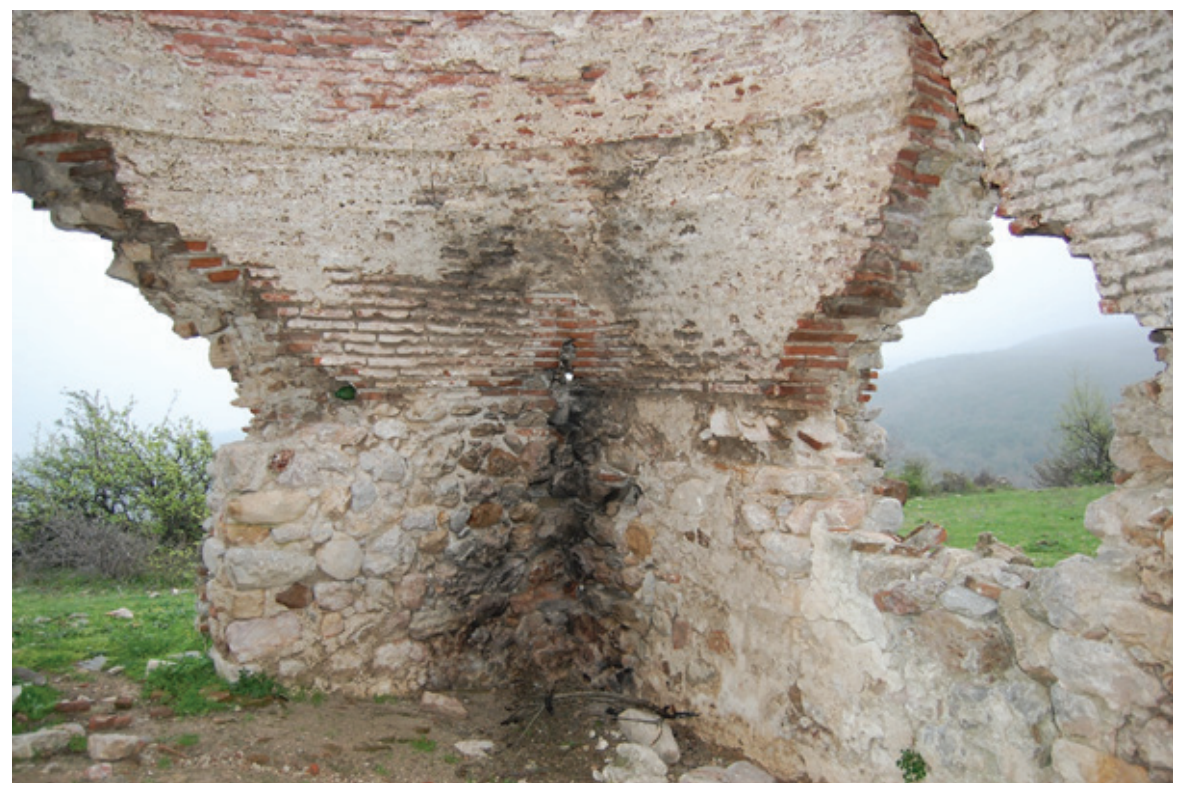


